\title{
Board Heterogeneity, Diversification Strategy and Firm Value
}

\author{
Bei Ye $\mathrm{e}^{1, \mathrm{a}}$ \\ ${ }^{1}$ College of Humanities, Law and Economics, Wuhan University of Science and Technology, Wuhan \\ 430065, Hubei, China \\ ayebei@wust.edu.cn
}

Keywords: board, heterogeneity, diversification, firm value

Abstract. Taking nonfinancial companies listed on Shanghai or Shenzhen stock exchange as the sample, the paper studies the relationship between board heterogeneity, diversification strategy and firm value. Empirical research shows that board occupational heterogeneity is positively related to corporate diversification and firm value, whereas social heterogeneity is negatively related to them; diversification strategy works partly as a mediator between board heterogeneity and firm value. The policy implication is that effective board construction should care more about reasonable allocation of board members' social or occupational features, so as to make the fullest use of the benefits of team heterogeneity via strategic role implementation.

\section{Introduction}

Diversification as an important strategic move brings opportunities and risks as well. How do boards of directors influence the formulation and implementation of this strategy so as to promote firm competitiveness? This is a topic of growing interest in recent years.

Previous study usually regards the board of director as one unity and discusses the relationship between the overall board characteristics and firm performance. However in reality board members differ in many ways such as gender, age, nationality, expertise and so on, which is called board heterogeneity. ${ }^{[1]}$ The Upper Echelons Perspective believes that team heterogeneity in terms of cognition, skills, social and professional experience provides different information and resources for decision-making so as to adapt easily to complex environment. ${ }^{[2]}$ Cognitive psychological research also finds that different backgrounds of team members help broaden their knowledge and prevent groupthinking. Therefore board heterogeneity may be beneficial to its strategic role fulfillment. However heterogeneity may cause diverse opinions and conflicts of interest, which increases coordination costs and reduce operation efficacy. ${ }^{[3]}$ This is especially evident during diversification. On one hand, companies at that time are faced with more complex environment and need more resources, which is often beyond management capabilities. Directors with diverse background may provide advice with their own knowledge and expertise; they can also make use of their social or professional network to facilitate the process of diversification. ${ }^{[4]}$ On the other hand, as a vital strategy in business development, smooth operation of diversification needs all directors' cognitive reconciliation and interest alignment, which is more difficult among heterogeneous directors.

This paper aims to empirically study the potential influences by board heterogeneity on corporate diversification strategy and firm value, with a sample of companies listed on China Shanghai or Shenzhen stock exchange. The study helps to make up the gap of existing literature, and provide empirical evidence for future governance reforms.

\section{Related Study and Research Hypotheses}

Related Study. Existing study on diversification focuses on motivation of diversification and its impact on corporate performance. In recent years, more attention has been paid to the role of strategy decision-makers.

The Resource Dependence Theory emphasizes the role of the board in the company's strategic behavior, arguing that directors' resources and their contact with the outside world help to reduce the 
organization's dependence on the external environment ${ }^{[5]}$. According to Hillman, company directors can be divided into several types such as insiders, business experts, support specialists, community influencers and so on; different types of directors provide different useful resources for the company ${ }^{[6]}$.

The Higher Echelon Theory suggests that demographic characteristics of the executives imply their task-related skills, experience, knowledge and information, and embody their cognitive characteristics and difference. Board members screen, select and interpret information they received based on their knowledge and values, and apply it to corporate strategic choice; therefore it is a good time to test the role of heterogeneity when the company is entering a new business area. ${ }^{[2]}$

Board heterogeneity is usually classified as occupational heterogeneity and social heterogeneity. The former refers to occupation related difference in professional background, tenure, education and so on; the latter refers to differences related to demographic features such as gender, age, race and so on. $\mathrm{Li}$ et al. believe that team occupational heterogeneity helps to stimulate debate in the process of decision-making, and thus is more important; social heterogeneity is linked with social processes, and helps to eliminate stereotypes, mistrust and emotional conflict ${ }^{[7]}$.

Above research tends to affirm the positive role of board heterogeneity in corporate strategic decision making. However some scholars point out that directors' difference in professional background and experience may reduce effective communication and coordination, and hinder them from reaching agreement on strategic issues. In short, board heterogeneity is a double-edged sword; the results of benefits versus costs depend on the nature of the issue under discussion ${ }^{[8]}$. Page argues that if the decision-making relies mainly on information and resources, the benefits of heterogeneity will be more evident; however, if the task requires more coordination between board members, heterogeneity will increase internal friction ${ }^{[9]}$.

Empirical research used to focus on the impact of demographic characteristics and education level of directors on corporate strategy and performance. Some scholars find female directors help improve corporate performance ${ }^{[10]}$; others find gender and ethnic background diversity help increase corporate value $^{[11]}$. The empirical study of Anderson et al. shows that directors' diversity in terms of citizenship and education background has a positive effect on corporate performance ${ }^{[12]}$. Chinese scholars Li and Xue empirically tested the effect of board expertise and networking resources on corporate diversification. They find that both expertise and networking resources of the board, especially political resources, help to increase the benefit of diversification ${ }^{[13]}$. Their research focused on the overall level of board expertise and resources, and did not consider the difference across board members.

\section{Research Hypotheses.}

1. Board heterogeneity and diversification strategy. As above mentioned, board heterogeneity includes social heterogeneity and occupational heterogeneity. Generally speaking, formulation and implementation of diversification require cross-industry knowledge and experience of decision-makers. In this respect, board occupational heterogeneity, especially the diversity of professional experience, will undoubtedly play a significant role. Different experience or expertise of directors enriches the information board receives. Convergence and collision of views help stimulate new thoughts and ideas, so as to provide better consulting service ${ }^{[14]}$. Multiple sources of information also help improve the accuracy of forecasting, so that investment decisions are well-founded ${ }^{[15]}$. Thus we put forward the following hypothesis:

H1 Board occupational heterogeneity is positively associated with firm diversification.

However, as any vital strategy, adoption of diversification strategy usually undergoes long-time discussion before reaching consensus. This process is greatly affected by cognitive features of directors, which are further affected by their age, gender, ethnicity and other demographic characteristics. Existing research shows that difference in gender, race and age often leads to social classifications of team members, resulting in small groups. Group members experience positive emotions, yet people excluded experience negative ones. This will hinder the team from better communication and cooperation. Williams and O'Reilly point out that homogeneous team leads to 
better cooperation, while demographic heterogeneity increases conflicts and reduces social integration ${ }^{[16]}$.Therefore the following hypothesis is put forward:

$\mathrm{H} 2$ Board social heterogeneity is negatively associated with firm diversification

2. Board heterogeneity and firm value. There have been two controversial viewpoints as for the effect of team heterogeneity on firm value. One is that heterogeneity allows team members to embrace more resources and therefore increases firm value; the other believes that heterogeneity intensifies conflict, and may do harm to firm value ${ }^{[17,18]}$.

As for diversification, since diverse knowledge, education background and professional experience of directors greatly enrich information and networking resources for the company, and may reduce decision-making errors under uncertainty, the positive effect of heterogeneity should exist in most cases. However the potential conflict and friction also grow with differences in directors' social property. This would increase the costs of pushing forward diversification strategy, and tends to reduce firm value. Therefore we have the following hypotheses:

H3 Board occupational heterogeneity has a positive effect on firm value.

H4 Board social heterogeneous has a negative effect on firm value.

3. Mediating effect of diversification strategy

Effect of diversification on firm value also varies. On one hand, companies with diverse businesses enjoy the benefits of scale economy. They can produce different products or provide different service with the same marketing resources, or operate in different industries with existing financial or judicial resources. On the other hand, some diversification is accompanied by misallocation of capital which greatly reduces firm value. Besides the agency problems are more prominent during the process of diversification ${ }^{[19]}$.

Considering the potential effects of board heterogeneity on diversification, we wonder if diversification fully or partly mediates the effect of board heterogeneity on firm value. That is to say, the occupational and social heterogeneity first affects the formulation and implementation of diversification strategy, then they affect firm value. The hypotheses are as follow:

H5 Diversification strategy mediates the impact of board occupational heterogeneity on firm value.

H6 Diversification strategy mediates the impact of board social occupational heterogeneity on firm value.

Fig.1 shows the potential relationship between board heterogeneity, diversification and firm value.

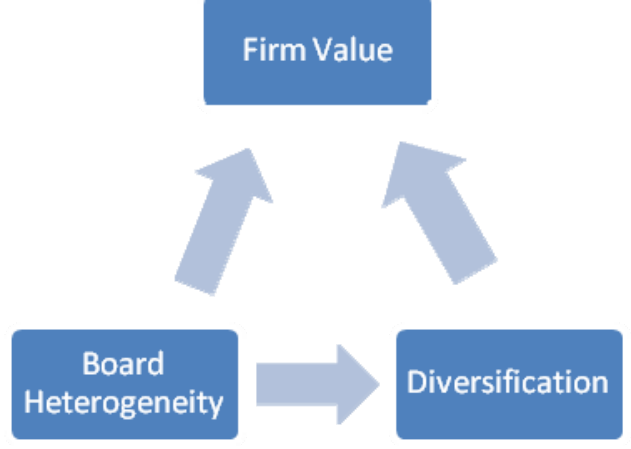

Fig.1 Board Heterogeneity, Diversification

\section{Empirical Analysis}

\section{Variables and Measures.}

1. Diversification. According to existing research, the degree of firm diversification may be measured by the number of sectors, entropy index, or diversity index. The first measure is based on certain coding method of industry sectors; however the result may be affected by different density in the coding system. The entropy index is calculated based on industrial clusters, which are hard to obtain according to information disclosure status-quo in China. Therefore in this study we calculated the diversity index using Blau coefficients, namely:

$$
D I V=1-\sum_{i=1}^{n} p_{i}^{2} \text {. }
$$


In Eq. $1, n$ refers to the number of sectors firm $i$ is engaged in; $p_{i}$ is the portion of its business revenue from a certain sector to its total business revenue. The measure is valued between 0 and 1 ; the higher DIV , the more diversified the firm is.

\section{Board Heterogeneity}

(1) Board occupational heterogeneity

Board occupational heterogeneity is obtained as follows:

$$
H P R O=H I N D+H E D U+H T E N U R E+H M U L T I D I R .
$$

In Eq.2, HIND、HEDU、HTENURE stand for board heterogenerity in professional background, education and tenure respectively. HMULTIDIR refers to how many directorships the director holds in other companies. This measure is included because it reflects the director's networking resources. Since tenure and number of directorships are both numeric, HTENURE and HMULTIDIR are measured by the coefficients of variance.

According to directors' resume information provided by GTA CSMAR Solution (a major securities market databank in China) or company annual reports, we classified their industry background into 6 categoriesgroups namely technology, marketing, management, human resources, legal, and other, then caculated board heterogeneity of industry background HIND using Blau coefficient as in Eq.1, in which $n$ is the number of industry background, $p_{i}$ is the portion of directors of a certain industry background in the board.

For HEDU we used similar method. Directors' education background was classifed into 6 levels namely (technical) secondary school, college, undergraduate, graduate,doctoral and other . We used Blau coefficients to measure heterogeneity, The education informcation was extracted from CCER Economic and Financial Database (a major databank of Chinese capital market) and company annual reports.

(2)Board social heterogeneity

At present, foreign directors in Chinese listed companies are rare. Therefore we only consider directors' difference in gender and age, namely HSEX and HAGE. The former used Blau coefficients; while the latter uses coefficients of variance. Board social heterogeneity HSO is the sum of HSEX and HAGE. Information on gender and age was extracted from GTA CSMAR Solution or company annual reports.

(3)Other variables

We use Tobin's Q to measure the business value of listed companies. Tobin's Q is obtained from CCER Economic and Financial Database.

Still as in existing study, the size of the company LNSIZE, return on assets ROA, asset-liability ratio DA were used as control variables. Among them, the size of the company adopted the natural logarithm of the total assets at the year end

Specification of the variables is shown in Table1. 
Table 1 Variables and Specification

\begin{tabular}{|c|c|c|c|}
\hline Variable type & Variable & Meaning & Specification \\
\hline $\begin{array}{l}\text { Dependent } \\
\text { variable }\end{array}$ & $\mathrm{Q}$ & Tobin Q & $\begin{array}{l}\text { Extracted from CCER Economic and Financial } \\
\text { Database }\end{array}$ \\
\hline \multirow[t]{8}{*}{$\begin{array}{l}\text { Explanatory } \\
\text { variables }\end{array}$} & HPRO & $\begin{array}{l}\text { Board occupational } \\
\text { Heterogeneity }\end{array}$ & $\begin{array}{l}H P R O=H I N D+H E D U+ \\
H T E N U R E+H M U L T I D I R\end{array}$ \\
\hline & HIND & $\begin{array}{l}\text { Board heterogeneity in industry } \\
\text { background }\end{array}$ & $\begin{array}{l}\text { H IN D }=1-\sum_{i=1}^{n} p_{i}^{2} \\
\mathrm{p}_{\mathrm{i}} \text { : the portion of directors of a certain industry } \\
\text { background in the board }\end{array}$ \\
\hline & HEDU & $\begin{array}{l}\text { Board heterogeneity in } \\
\text { education }\end{array}$ & $\begin{array}{l}H E D U=1-\sum_{i=1}^{n} p_{i}^{2} \\
\mathrm{p}_{i} \text { the portion of directors of a certain education } \\
\text { level in the board }\end{array}$ \\
\hline & HTENURE & Board heterogeneity in & Coefficent of variance \\
\hline & HMULTIDIR & $\begin{array}{l}\text { Board heterogeneity in } \\
\text { directorships in other companies }\end{array}$ & Coefficent of variance \\
\hline & HSO & Board social heterogeneity & $H S O=H S E X+H A G E$ \\
\hline & HSEX & Board heterogeneity in gender & $\begin{array}{l}H S E X=1-\sum_{i=1}^{n} p_{i}^{2} \\
\mathrm{p}_{\mathrm{i}} \text { :the portion of male or female directors in the } \\
\text { board }\end{array}$ \\
\hline & HAGE & Board heterogeneity in age & Coefficent of variance \\
\hline Mediator & DIV & Degree of diversification & $\begin{array}{l}D I V=1-\sum_{i=1}^{n} p_{i}^{2} \\
p_{i}: \text { the portion of business revunue from a certain sector } \\
\text { in the total business revenue }\end{array}$ \\
\hline \multirow[t]{3}{*}{ Control variable } & ROA & Ratio of return over assets & Net income/total assets \\
\hline & DA & Asset-liability ratio & debt/assets \\
\hline & $\operatorname{lnSIZE}$ & Firm size & natural logarithm of the total assets \\
\hline
\end{tabular}

Research Model. Based on previous analysis, we propose two research models as follow:

$$
\begin{aligned}
& Q=\beta_{0}+\beta_{1 \sim 2} H+\beta_{3-5}(\text { Control })+\varepsilon . \\
& Q=\beta_{0}+\beta_{1 \sim 2} H+\beta_{3 \sim 5}(\text { Control })+\beta_{6} D I V+\varepsilon .
\end{aligned}
$$

In above models, $H$ stands for heterogeneity measures. Model 1is used to test effect of board heterogeneity on firm value; Model 2 is used to test potential mediating effect of diversification strategy in above process.

To avoid multicollinearity, we try to keep the models as concise as possible, excluding some insignificant variables according to previous study.

Sample and Data. The sample was taken from A-share non-financial companies listed on Shanghai and Shenzhen Stock Exchanges of China in 2013. We excluded companies in irregular trading status, companies lacking necessary data, and companies with abnormal data. The final sample consisted of 1357 observations. Research data were obtained from CCER Economic and Financial Database, GTA Data, and company annual reports.

Descriptive Statistics. Table 2 shows descriptive /frequency statistics of our sample companies. As shown in the table, average age of the 13431 directors in the sample companies is 49.57. As for 
industry background, 38.8\% of the directors have a background of economics and administration; $31.1 \%$ of them have a background of technology. About $60.7 \%$ of the directors have a master's or even higher degree, which shows that the overall education level of directors are relatively high. As for gender composition, male directors still dominate, with a percentage of $86.5 \%$.

Table 2 Descriptive/ Frequency Statistics of Sample Boards

\begin{tabular}{|c|c|c|c|c|c|c|c|c|}
\hline & $\mathrm{N}$ & & Minimum & $\begin{array}{c}\text { Maximu } \\
\mathrm{m}\end{array}$ & Mean & \multicolumn{3}{|c|}{ Standard deviation } \\
\hline tenure & & 13431 & 1 & 18 & 4.27 & \multicolumn{3}{|c|}{2.525} \\
\hline age & & 13431 & 23 & 85 & 49.57 & \multicolumn{3}{|c|}{8.644} \\
\hline $\begin{array}{l}\text { Industry } \\
\text { background }\end{array}$ & Frequency & $\%$ & Education level & Frequency & $\%$ & Gender & FreQuency & $\%$ \\
\hline technology & 4176 & 31.1 & $\begin{array}{l}\text { (technical) } \\
\text { secondary or } \\
\text { below }\end{array}$ & 3290 & 24.5 & male & 11613 & 86.5 \\
\hline marketing & 370 & 2.8 & undergraduate & 190 & 1.4 & female & 1818 & 13.5 \\
\hline $\begin{array}{l}\text { business ad- } \\
\text { ministration }\end{array}$ & 5214 & 38.8 & graduate & 4466 & 33.3 & total & 13431 & 100.0 \\
\hline $\begin{array}{l}\text { human } \\
\text { resources }\end{array}$ & 66 & 0.5 & doctoral & 3681 & 27.4 & & & \\
\hline law & 903 & 6.9 & other & 1804 & 13.4 & & & \\
\hline other & 2702 & 20.1 & total & 13431 & 100.0 & & & \\
\hline total & 13431 & $\begin{array}{r}100 . \\
0 \\
\end{array}$ & & & & & & \\
\hline
\end{tabular}

Table 3 shows descriptive statistics of the research variables.

Table 3 Descriptive Statistics of Variables

\begin{tabular}{l|l|l|l|l|l}
\hline & $\mathrm{N}$ & Minimum & Maximum & \multicolumn{1}{c}{ Mean } & $\begin{array}{c}\text { Standard } \\
\text { deviation }\end{array}$ \\
\hline $\mathrm{Q}$ & 1357 & 1.000 & 25.000 & 1.853 & 1.292 \\
\hline HPRO & 1357 & 0.786 & 4.382 & 1.995 & 0.416 \\
\hline HIND & 1357 & 0.000 & 0.857 & 0.618 & 0.128 \\
\hline HEDU & 1357 & 0.000 & 0.996 & 0.660 & 0.206 \\
\hline HTENURE & 1357 & 0.000 & 3.162 & 0.537 & 0.294 \\
\hline HMULTIDIR & 1357 & 0.000 & 0.962 & 0.179 & 0.214 \\
\hline HSO & 1357 & 0.037 & 0.789 & 0.369 & 0.176 \\
\hline HSEX & 1357 & 0.000 & 0.500 & 0.207 & 0.161 \\
\hline DAGE & 1357 & 0.037 & 0.347 & 0.162 & 0.054 \\
\hline ROA & 1357 & 0.000 & 0.887 & 0.154 & 0.225 \\
\hline DA & 1357 & -51.000 & 59.000 & 3.820 & 5.984 \\
\hline LNSIZE & 1357 & 1.000 & 109.000 & 39.172 & 21.306 \\
\hline & 1357 & 18.000 & 28.000 & 21.665 & 1.143 \\
\hline
\end{tabular}

As shown in Table 3, board occupational heterogeneity in education is larger than that in industry background, with a mean of 0.660 and 0.618 respectively.

As for social heterogeneity, gender heterogeneity is very small, with the mean of 0.207 . Combining this with the frequency statistics in Table 2, we find that male dominance is prevalent across listed companies in China, therefore there is not much difference in gender distribution. Similarly, the age heterogeneity has a mean of only 0.162, suggesting that age distribution of directors is relatively concentrated.

The standard deviation of DIV (0.225) is much higher compared with the mean (0.154), implying that diversification varies a lot across sample companies.

Correlation Analysis. Table 4 shows the Pearson correlation analysis results between each pair of variables. 
Table 4 Pearson Correlation of Variables

\begin{tabular}{|c|c|c|c|c|c|c|c|c|c|c|c|c|c|}
\hline & $\mathrm{Q}$ & & ROA & & DA & & LNSIZI & & HSO & & HPRO & & DIV \\
\hline $\mathrm{Q}$ & 1 & & & & & & & & & & & & \\
\hline ROA & .162 & $* * *$ & 1 & & & & & & & & & & \\
\hline DA & -195 & $* * *$ & -.369 & $* * *$ & 1 & & & & & & & & \\
\hline LNSIZE & -.362 & $* * *$ & .028 & & .518 & $* * *$ & 1 & & & & & & \\
\hline HSO & .007 & & .066 & $* *$ & -.103 & $* * *$ & -.112 & $* * *$ & 1 & & & & \\
\hline HPRO & .037 & & -.079 & $* * *$ & .157 & $* * *$ & .120 & $* * *$ & -.054 & ** & 1 & & \\
\hline DIV & .011 & & -.048 & * & .171 & $* * *$ & .110 & $* * *$ & -.074 & $* * *$ & .045 & * & 1 \\
\hline
\end{tabular}

${ }^{* * *} \mathrm{p}<0.01 ; * * \mathrm{p}<0.05 ; * \mathrm{p}<0.10$ (two-tailed).

As shown in Table 4, firm value is positively related to ROA at $1 \%$ significance level, but negatively related to financial leverage and firm size at $1 \%$ significance level. Board social heterogeneity is negatively related to diversification degree at $1 \%$ significance level; occupational heterogeneity is positively related to diversification, though at a marginal significance level of $10 \%$. The results generally give support to hypotheses $\mathrm{H} 1$ and $\mathrm{H} 2$.

However in the Pearson Correlation analysis, there is no significant relationship between either board heterogeneity or diversification and firm value. The reason might be that heterogeneity and diversification work on firm value in an indirect or subordinate way and their effect is affected by other factors. Therefore we conducted a partial correlation analysis by controlling ROA, DA and firm size. The results are as shown in Table 5.

Table 5 Partial Correlation between Board Heterogeneity/Diversification and Firm Value

\begin{tabular}{c|l|llllll}
\hline Control variable & Variable & \multicolumn{2}{|c}{ Q } & HSO & HPRO & DIV \\
\hline ROA \& LNSIZE \& DA & Q & 1.000 & & & & & \\
& HSO & -0.049 & $*$ & 1.000 & & \\
& HPRO & 0.096 & $* * *$ & -0.034 & 1.000 & \\
& DIV & .055 & $* *$ & -.057 & $* *$ & .017 & 1.000 \\
\hline
\end{tabular}

This time board social heterogeneity is negatively related to firm level at a $10 \%$ significance level; occupational heterogeneity is positively related to firm value at a $1 \%$ significance level. Both results tend to support hypotheses H4 and H3. Firm diversification level DIV is positively related to firm value $(\mathrm{p}<5 \%)$. It suggests that in general diversification tends to increase firm value.

Multivariate Linear Regression Analysis. We ran multivariate linear regressions with Model 1 via SPSS20 to test effects of board heterogeneity on firm value. Table 6 shows the regression results with standardized coefficients.

Table 6 Regression of Board Heterogeneity on Firm Value

\begin{tabular}{|c|c|c|c|c|c|c|c|c|}
\hline & (1) & & (2) & & (3) & & (4) & \\
\hline ROA & .212 & $* * *$ & .216 & $* * *$ & .216 & $* * *$ & .218 &.$^{* * *}$ \\
\hline DA & .102 & $* * *$ & .102 & $* * *$ & .093 & $* * *$ & .093 & $* * *$ \\
\hline LNSIZE & -.421 & $* * *$ & -.427 & $* * *$ & -.427 & $* * *$ & -.433 & $* * *$ \\
\hline HSO & & & -.054 & $* *$ & & & -.047 &.$^{*}$ \\
\hline HPRO & & & & & .084 & $* * *$ & .080 &.$* * *$ \\
\hline $\mathrm{R}^{2}$ & .167 & & .170 & & .174 & & .176 & \\
\hline AdjustedR $^{2}$ & .165 & & .168 & & .172 & & .173 & \\
\hline $\mathrm{F}$ & 91.299 & $* * *$ & 69.818 & $* * *$ & 71.845 & $* * *$ & 58.282 & $* * *$ \\
\hline Obs & 1357 & & 1357 & & 1357 & & 1357 & \\
\hline
\end{tabular}

*** $\mathrm{p}<0.01 ; * * \mathrm{p}<0.05 ;{ }^{*} \mathrm{p}<0.10$ (two-tailed).

Column (1) shows regression results when heterogeneity is not included. Consistent with most financial study, ROA and DA ratio show significant and positive effects on firm value, which means 
profitability and financial leverage help increase firm value. Firm size shows a significant but negative effect on firm value. One possible reason is when a company grows in size, its adaptability to the outside environment might decrease, thus harm its firm value.

Column (2) (4) introduce board heterogeneity factors into the model. Regression results show that board occupational heterogeneity HPRO always has significant positive effects $(\mathrm{p}<1 \%)$ on firm value, while board social heterogeneity has a negative effect and at less significant level (5\% in column (2) and 10\% in column (4)). On the whole, the results are consistent with Hypotheses H3and H4. The increased adjusted $\mathrm{R}^{2}$

Shows that the introduction of board heterogeneity factors increased the overall fit of the model.

Following the procedures proposed by Wen et al. ${ }^{[20]}$, we then tested if diversification strategy mediates between board heterogeneity and firm value.

As the first step, we centralized all the variables (beginning with "C"), and ran multivariate linear regressions with Model 1. The results are shown in column (1), (3) and (5) of Table 7.

Table 7 Mediating Effects of Diversification Strategy

\begin{tabular}{|c|c|c|c|c|c|c|c|c|c|c|c|c|}
\hline \multirow[b]{2}{*}{ CROA } & \multicolumn{2}{|l|}{ (1) } & \multicolumn{2}{|c|}{ (2) } & \multicolumn{2}{|l|}{ (3) } & \multicolumn{2}{|c|}{ (4) } & \multicolumn{2}{|c|}{ (5) } & \multicolumn{2}{|c|}{ (6) } \\
\hline & .216 & $* * *$ & .213 & $* * *$ & .216 & $* * *$ & .213 & $* * *$ & .218 & $* * *$ & .215 & $* * *$ \\
\hline CDA & .102 & $* * *$ & .093 & $* * *$ & .093 & $* * *$ & .084 & $* * *$ & .093 & $* * *$ & .085 & $* * *$ \\
\hline CLNSI & -.427 & $* * *$ & -.428 & $* * *$ & -.427 & $* * *$ & -.427 & $* * *$ & -.433 & $* * *$ & -.432 & $* * *$ \\
\hline \multicolumn{13}{|l|}{$\mathrm{ZE}$} \\
\hline CHSO & -.054 & $* *$ & -.051 & $* *$ & & & & & -.047 & * & -.045 & * \\
\hline CHPR & & & & & .084 & $* * *$ & .081 & $* * *$ & .080 & $* * *$ & .077 & $* * *$ \\
\hline \multicolumn{13}{|l|}{$\mathrm{O}$} \\
\hline CDIV & & & .049 & * & & & .049 & $* *$ & & & .046 & $*$ \\
\hline $\mathrm{R}^{2}$ & .170 & & .172 & & .174 & & .176 & & .176 & & .178 & \\
\hline Adjusted R ${ }^{2}$ & .168 & & .169 & & .172 & & .173 & & .173 & & .174 & \\
\hline $\mathrm{F}$ & 69.818 & $* * *$ & 56.147 & $* * *$ & 71.845 & $* * *$ & 57.629 & $* * *$ & 58.282 & & 48.631 & $* * *$ \\
\hline Observations & 1357 & & 1357 & & 1357 & & 1357 & & 1357 & & 1357 & \\
\hline
\end{tabular}

As shown in columns (1) and (5), board social heterogeneity shows significant negative effect on firm value; as shown in columns (3) and(5), occupational heterogeneity shows significant positive effect on firm value. These meet the requirements of the first step of mediating effect test procedures.

As the second step, we analyzed Pearson correlation between heterogeneity factors and diversification, with results listed in Table 8.

Table 8 Pearson Correlation of Heterogeneity and Diversification

\begin{tabular}{|c|c|c|c|}
\hline & CDIV & CHSO & CHPRO \\
\hline CDIV & 1 & & \\
\hline CHSO & $-0.084 * * *$ & 1 & \\
\hline CHPRO & $0.063^{* *}$ & $-0.108^{* * *}$ & 1 \\
\hline
\end{tabular}

It shows that both types of heterogeneity are significantly related to diversification, which meets the second requirement of mediating effect test procedures.

Then we introduced the variable of diversification and ran multivariate linear regressions with Model 2. The results are shown in columns (2),(4) and (6) of Table 7.

As in Column (2) of Table 7, with introduction of diversification, board social heterogeneity still has a negative effect on firm value at a $5 \%$ significance level, however the coefficient absolute value decreases from 0.054 to 0.051 ; meanwhile diversification shows a positive effect on firm value at a 
marginal significance level of $10 \%$. This implies that diversification partly mediates the effect of social heterogeneity on firm value.

As in Column (4) of Table 7, with introduction of diversification, board occupational heterogeneity still has a positive effect on firm value at a $1 \%$ significance level, however the coefficient decreases from 0.084 to 0.081 ; meanwhile diversification shows a positive effect on firm value at a 5\% significance level. Therefore diversification partly mediates the effect of occupational heterogeneity on firm value.

Column (6) of Table 7 combined both types of heterogeneity and diversification into the model. With introduction of diversification, board social heterogeneity shows a negative effect on firm level at a $10 \%$ significance level; occupation heterogeneity shows a positive effect on firm value at a $1 \%$ significance level. However the absolute value of both coefficients reduces a bit. At the same time, diversification is positively related to firm value at a marginal significant level of $10 \%$. Still these results show that diversification partly mediates the effects of board social and occupational heterogeneity on firm value.

All in all, the above findings give supports to hypotheses $\mathrm{H} 5$ and H6.

In the end, we conducted multicollinearity tests for all above regressions. The maximum variance inflation factor is 1.75 , and the minimum tolerance is 0.571 , which suggests there should be no serious problems of multicollinearity.

\section{Robustness Test}

For robustness test, we first substituted detailed social heterogeneity measures HSEX and HAGE for HSO, and detailed occupational heterogeneity measures HIND, HEDU, HTENURE and HMULTIDIR for HPRO, and repeated above study.

With regressions on Model 1, we find that: in terms of social heterogeneity, only age heterogeneity shows a significant negative effect on firm value. As for occupational heterogeneity, both education and tenure heterogeneity show significant effect on firm value. There is no significant relationship between HSEX, HIND or HMULTIDIR and firm value.

Therefore we deleted the insignificant heterogeneity variables, and tested the potential mediating effect of diversification following above-mentioned procedures. The results are shown in Table 9.

Table 9 Robust Test using Detailed Heterogeneity Measures

\begin{tabular}{|c|c|c|c|c|c|c|}
\hline & \multicolumn{2}{|c|}{$(1)$} & \multicolumn{2}{|c|}{$(2)$} & \multicolumn{2}{|l|}{ (3) } \\
\hline CROA & .217 & $* * *$ & .217 & $* * *$ & .214 & $* * *$ \\
\hline CDA & .084 & $* * *$ & .085 & $* * *$ & .078 & $* *$ \\
\hline CLNSIZE & -.434 & $* * *$ & -.432 & $* * *$ & -.433 & $* * *$ \\
\hline CHSEX & -.016 & & & & & \\
\hline CHAGE & -.073 & $* * *$ & -.076 & $* * *$ & -.075 & $* * *$ \\
\hline CHEDU & .070 & $* * *$ & .072 & $* * *$ & .071 & $* * *$ \\
\hline CHTENURE & .073 & $* * *$ & .073 & $* * *$ & .072 & $* * *$ \\
\hline CHIND & -.015 & & & & & \\
\hline CHMULTIDIR & .008 & & & & & \\
\hline CDIV & & & & & .043 & $*$ \\
\hline $\mathrm{R} 2$ & 0.184 & & 0.184 & & .186 & \\
\hline AdjustedR $^{2}$ & 0.179 & & 0.18 & & .181 & \\
\hline F & 34.151 & $* * *$ & 51.168 & $* * *$ & 43.953 & $* * *$ \\
\hline Observations & 1352 & & 1352 & & 1352 & \\
\hline
\end{tabular}

With the introduction of diversification variable, the effect of HAGE, HEDU and HTENURE on firm value are still significant, except that the absolute value of their coefficient reduces a little bit; at the same time, diversification shows a positive effect on firm value at a $10 \%$ significance level. 
All in all, the robustness test supports a partial mediating effect of diversification between board heterogeneity in age, education, tenure and firm value.

\section{Conclusion}

Diversification is a vital strategic choice. The board of directors, as the most important decision-maker in modern companies, plays a key role during this process. In spite of previous study on board characteristics and corporate performance, little attention has been paid to board heterogeneity and its potential impact on diversification and its performance.

This study tries to empirically test the relationship between board heterogeneity, diversification and corporate performance with a sample of non-financial companies listed on Shanghai or Shenzhen stock exchanges of China. The results suggest that:

(1) Board occupational heterogeneity contributes to corporate diversification and firm value. Directors' difference in education, experience, knowledge and networking resources brings more information for making decisions, and helps decrease uncertainty during diversification, thus increases firm value. Among various types of occupational heterogeneity, difference in education and tenure appear more evident than that in industry background and number of directorships.

(2) Board social heterogeneity tends to reduce inclination for diversification and shows a negative impact on firm value. The reason might be that demographic difference tends to increase potential conflicts, therefore might hinder successful communication and reaching agreement. A further study shows that between the two types of social heterogeneity considered, difference in age is more prominent; while difference in gender composition is not as significant as expected. The reason might be that boards of directors in China are still dominated by male directors.

(3) Diversification strategy partly mediates the impact of board heterogeneity on firm value. The empirical test shows that after introduction of diversification in the model, the significant impacts by board occupational and social heterogeneity still exist, but reduce in magnitude; at the same time diversification itself shows significant and positive effect on firm value. This suggests that board heterogeneity does not work on firm value in a direct way. In most cases, it works via the board's involvement in strategy formulation and implementation. Therefore it is not enough to focus on the static arrangement of the board structure; instead we should pay more attention to how the structure affects the board decision-making process and strategic role fulfillment.

The above findings provide important implications for the ongoing reforms of board of directors. In the real world, any board of directors is made up of people with different backgrounds and features. This difference should be cherished and better utilized. To build up effective boards, we should allocate more directors with different knowledge, expertise and resources so as to enlarge the benefits of occupational heterogeneity. At the same time, it is advisable to control the gap in social demographic features so as to reduce costs of coordination and negotiation. All in all, a harmonious but divergent board of directors will benefit strategy implementation such as diversification, and help increase firm value.

\section{Acknowledgements}

This work was financially supported by the China National Social Science Foundation(No. 12BGL047).

\section{References}

[1] X.Q. Li: Research on the Board Cognitive Heterogeneity to Firm Value. Research on Economics and Management Vol. 8(2012), p.14-22

[2] D.C. Hambrick and P.A. Mason: Upper Echelons: the Organization as a Reflection of its Top Managers. The Academy of Management Review Vol. 9(1984), p. 193-206 
[3] A.C. Amason: Distinguishing the Effects of Functional and Dysfunctional Conflict on Strategic Decision Making: Resolving a Paradox for Top Management Teams. Academy of Management Journal Vol. 39 (1996), p. 23- 148.

[4] J. Lorsch and E. Maclver: Pawns or Potentates: the Reality of America's Corporate Boards. Harvard Business School Press, Cambridge, MA(1989)

[5] J. Pfeffer and G.R. Salancik: The External Control of Organization: a Resource Dependence Perspective. Harper \& Row, New York (1978)

[6] A.J. Hillman and T. Dalzie: Boards of Directors and Firm Performance: Integrating Agency and Resource Dependence Perspectives. Academy of Management Review Vol 28 (2003), p.383-396

[7] W.A. Li, Z.J. Liu and L. Gu: Heterogeneity, Faultlines of the Board and Cross-border M\& A .Journal of Management Science Vol. 27(2014), p.1

[8] J.Vigdor: Community Composition and Collective Action: Analyzing Initial Mail Response to the 2000 Census. Review of Economics and Statistics Vol. 86(2004), p.303-312

[9] S. Page: The Difference: How the Power of Diversity Creates Better Groups, Firms, Schools and Societies. Princeton University Press, Princeton, NJ (2007)

[10] K. Ahern and D. Amy: The Changing of the Boards: the Impact on Firm Valuation of Mandated Female Board Representation. Quarterly Journal of Economics Vol.127( 2012), p. 137-197

[11] D.A. Carter, J.S. Betty and W.G. Simpson: Corporate Governance, Board Diversity, and Firm Value. Financial Review Vol.38(2003),p. 33-53

[12] R. Anderson, D. Reeb, A. Upadhyay and W. Zhao: The Economics of Director Heterogeneity. Financial Management Vol. 40(2011), p. 5-38

[13] G.D. Li and Y.Z. Xue: Study on Board Strategic Involvement Effects for Diversified Firms. Journal of Shanxi Finance and Economics University Vol.34(2012), p.96-103

[14] I.D. Steiner: Models for Inferring Relationships between Group Size and Potential Group Productivity. Behavioral Science Vol.11(1966),p. 273-283

[15] A. Sibert: Monetary Policy Committees: Individual and Collective Reputations. Review of Economic Studies Vol. 70( 2003), p. 649-665

[16] K.Y. Williams and C.A. O'Reilly: Demography and Diversity In Organizations: A Review of 40 Years of Research. Research in Organizational Behavior Vol.20( 1998), p.77-140

[17] J. Liu and Y. Xu: Team Diversity: Measurement, Outcomes and Moderators. Advances in Psychological Science Vol.14(2006), p.636-640

[18] C. A. Ooi, C. EW. Hooy, and A. P. M. Som: Diversity in human and social capital: Empirical evidence from Asian tourism firms in corporate board composition. Tourism Management Vol.48 (2015), p.139-153

[19] M.C. Jensen: The Modern Industrial Revolution,Exit,and the Failure of Internal Control Systems. Journal of Finance Vol.48(1993), p.831- 880

[20] Z.L. Wen, L. Zhang, J.T. Hou and H.Y. Liu: Testing Procedures of Mediating Effects and their Application(in Chinese). Acta Psychologica Sinica Vol. 36(2004), p.614-620 